\title{
Issues in developing communication strategies for implementing child-friendly city policies
}

\author{
Ranny Surya Maharani Soeharnis 1,* $^{*}$ and Bambang Shergi Laksmono ${ }^{1}$ \\ ${ }^{1}$ Department of Social Welfare, Faculty of Social and Political Sciences, Universitas Indonesia, Kampus UI \\ Depok, Depok 16424, Indonesia
}

\begin{abstract}
This study reveals important dimensions related to successful means communication in the implementation of the Child-Friendly City (CFC) Policies in Indonesia. The study was conducted in Kabupaten Bogor, West Java. It finds that communication strategy is the critical in disseminating the CFC policy. Thus, the development of the communication strategy for the CFC policy needed to involve the elements of communication as a whole. Furthermore, the communication strategy for the CFC policy required cooperation between local governments and children's groups. This research fills the gaps not yet addressed in the previous studies and shows communication strategy is an influential strategy for the successful implementation and development of the CFC policy. Our findings contribute to the development of the communication strategy for a sustainable CFC policy that communication aspect is very important in designing a policy.
\end{abstract}

\section{Introduction}

Indonesia ratified the Convention of the Rights of the Child (CRC) through Presidential Decree Number 36 Year 1990 on the Ratification of the Convention on the Rights of the Child. This decree stated that the country has a responsibility to fulfill, protect, and respect children's rights. Initiated by the Ministry of Women Empowerment and Child Protection, the CFC policy was adopted by the Republic of Indonesia as a state responsibility to help Indonesian children prosper. "KPPPA gives appreciation by assigning five categories of awards based on category achievement, namely category 'Pratama,' 'Madya,' 'Nindya,' 'Utama,' and the highest 'KLA/ CFC'" $[1]$.

Kabupaten Bogor granted a national award for its implementation of the CFC Policy. In August 2016, Kabupaten Bogor was named the top provincial level Child Friendly Kabupten after achieving the Pratama category twice. As a child welfare initiative, CFC development strategy should always be conducted consistently and sustainably in accordance with the needs and garner local community's potential. "One of the strategies for implementing child-friendly policies in Indonesia is promotion, communication, information, and education (PCIE) using the CFC policy advocacy material being compiled by the KPPPA"[2].

Several studies have been conducted on the CFCs in various countries. Eliana Riggio's (2002) study, Child Friendly Cities: Good Governance in the Best Interests of the Child, depicted the

\footnotetext{
*Corresponding author: ranny.soeharnis@gmail.com
} 
characteristics, legal basis, and institutional, budgeting, and planning steps to support a child friendly city. This study described how the CFC concept was being developed and implemented in different cities. "It illustrates the principles and practice of CFC through examples from various countries, including Spain, the Palestinian territories, Croatia, Ecuador, Brazil, India, Bangladesh, Sweden, Lebanon, Albania, and Ukraine" [3]. Marco Corsi's (2002) study, The Child Friendly Cities Initiative in Italy discussed "the strengths and limitations of different child friendly cities initiatives in Italy and the many measures by national, regional and local governments to support them. These measures include a new law, a national plan of action, more funds and an award available to the cities that achieve the most. City initiatives have sought to respond to the constraints that industrialization and urbanization have placed on children's safe mobility, use of city space and paticipation "[4].

However, among the strategies for developing a CFC policy, little has been said about the role of communication means or strategies. It is beleived that through effective communication, governments could easily promote policies, programs, and activities that promote child welfare. However, little has been noted about the effectivenes of of communication means in disseminating policies regarding child welfare issues.

\section{Material and Methods}

This research uses a descriptive, qualitative approach. As such, it focuses on the aspects of the process and meaning of social reality that cannot be strictly tested or measured in terms of quantity or frequency. "The focus of a qualitative study is to portrayhow social phenomena emerge and gain meaning" [5]. The qualitative approach in this study focuses on the development of PCIE strategy to promote CFC policy in Kabupaten Bogor. The study attempts to describe the process of the PCIE strategy implementation in the CFC policy.

The research location selected was Kabupaten or Regency of Bogor, Kecamatan Cibinong (Cibinong Sub-district). This location was selected because of its demographic features. According to West Java's provincial government, in 2015, "Kabupaten Bogor had the largest population in West Java at 4.966.621" [6]. Moreover, this location was selected because ofts efforts to implement CFC policies after being awarded first place among Child Friendly Kabupaten (regency) in West Java in 2016.

To obtain the necessary data and information, we used several data collection techniques, such as in-depth interviews with competent informants. These included division heads and subdivision heads in the Women Empowerment, Child Protection, Population Control, and Family Planning Agency - Pemberdayaan Perempuan, Perlindungan Anak, Pengendalian Penduduk, dan Keluarga Berencana (DP3AP2KB), Kabupaten Bogor (previously the Female Empowerment and Family Planning Agency/BPPKB); PR staff at the Communication and Information Agency (Diskominfo) in Kabupaten Bogor, the regional unit that facilitates the dissemination of CFC policy; and the target audience members including parents and children living in Kabupten Bogor. In addition, we held a Focus Group Discussion (FGD) with the Children's Forum in Kabupaten Bogor with child representatives in Kabupaten Bogor. Our research included also observation and a literature review.

\section{The Elements of Communication in CFC Policy Implementation in Kabupaten Bogor}

\subsection{Speaker}


At the Bogor regency level, CFC policy is implemented by the DP3AP2KB (the office for Women Empowerment, Child Protection, Population Control, and Family Planning Agency). According to an in-depth interview with SU (a sub-division head of the DP3AP2KB Kabupaten Bogor, 03/13/17), "The DP3AP2KB coordinates CFC policy. However, based on the task force selects the Regent as a supervisor, the DP3AP2KB as a chief, and the other agencies as the coordinator this policy."

$\mathrm{SH}$ (an informant, as the division head at the DP3AP2KB in Kabupaten Bogor, 03/13/17) said, "We currently informs CFC related programs and activities through public dissemination and workshops, and invite children from representative schools in Bogor regency surroundings. Alternatively, we bring roadshow materials to schools. If the event is conducted in this office, usually the sub-division head, agency head, or I will give a speech. However, we also often invite experts on children as speakers."

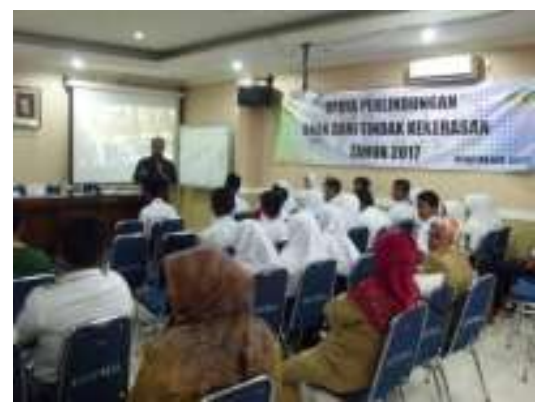

Fig. 1. The child protection effort worskhop from victim of violence 2017

This study observed that the DP3AP2KB of Kabupaten Bogor had asked a the Children's Forum to cooperate in disseminating policy information, activities, and CFC policy service. Informant SH added, "The Children's Forum assists us in marketing the CFC policy, for instance, to socialize the schools, because they are more interesting to the students. But fortunately, the kids are smart. The forum has already been developed, because they represent the province." Similarly, informant RA (the Children's Forum facilitator for Kabupaten Bogor, 03/29/17) said, "The Children's Forum here is often asked to serve as a speaker in the DP3AP2KB events. Age matters in this, so the information materials will be easier to deliver and understood."

Informant RN (a parent in Kecamatan Ciawi, Kabupaten Bogor, 03/21/17) stated that she/he has seen outdoor billboards near home, but was unable to understand the content of the message.

RN said that he/she does not understand what constitutes children's rights, and which which becomes the parents' obligation. RN thought that the billboard message should clarify and state clearly the obligations that parents have to fulfill The same idea was also expressed by informant HR (a child who lives in Kecamatan Ciawi, Kabupaten Bogor, 03/21/17). HR had seen the billboard nearby, but did not know the rights she/he had as a child. For CI, the only children's rights were for a chance to go to school and access to health care. 


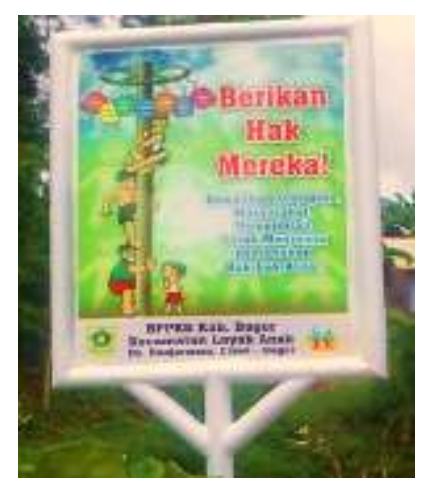

Fig. 2. Outdoor billboard on children's rights in village in Kabupaten Bogor Billboard text: "Fulfill Their Rights! It is the responsibility of parents, society, and government to secure children's rights."

Meanwhile, informant TM (a parent living in Kecamatan Ciomas, Kabupaten Bogor, 03/21/17) reported seeing the billboard and its message about Child Friendly Kabupaten. However he did not understand the message TM said, "Yes, I've seen there was an advertisement about Child Friendly Kabupaten on the roadside near to my house. It has a large picture of Bupati (the Head of Regent). But I don't understand what Child Friendly Kabupaten is." Consistent with the sentiments of Y1, NB (a child living in Kecamatan Ciomas, Kabupaten Bogor, 03/21/17) said, "Yes, I've often seen it. In my opinion, the message is not clear. The presentation is not attractive. I feel lazy about reading a book, and even more so about reading that advertisement." RZ added, "The average advertisement about CFC is not attractive and not everyone will understand its meaning."

\subsection{Channel}

Informant $T$ (a child living in Cibinong Sub-district, Kabupaten Bogor, 03/21/17) mentioned that she had seen the billboard in the Cibinong area. Yet, she did not remember the message because it was hidden by a tree and finds the panel damaged. During a field observation (in 05/20/2017), this billboard of CFC Policy was not found in the location.

Informant RZ (the Children's Forum facilitator for Kabupaten Bogor, 03/26/17) said, "The workshop and the DP3AP2KB socialization participants are the child representatives in Kabupaten Bogor." Hence, they were the only ones who obtained detailed knowledge about the CFC initiatives in Kabupaten Bogor. If they are active and have a responsibility, they could disseminate this information to their friends in school.

\section{Communication Elements and the Strategy for Disseminating CFC Policy}

With a goal to foster understanding and rise awareness, the media was used to foster stakeholder's communication and information dissemination and further internalise the CFC principles. The media in this case can be classified into indoors, outdoors, printed, electronic, and electronic web-based or social media. We found that the use of the PCIE strategy for the CFC policy in Kabupaten Bogor only emphasized media use for promotion, information, and education on CFC policy for target audiences. As part of its communication strategy, the PCIE should consider also communication elements consisting of a) Speaker; (b) Message; (c) Channel; (d) Receiver; and (e) Effect. 


\subsection{Speaker}

In the CFC policy implementation in Kabupaten Bogor, the DP3AP2KB serves the role of communicator of the CFC initiatives. The communication role in message delivery to the target audience is crucial. In planning a communication strategy to disseminate the CFC initiatives, the selection of a communicator suitable for the message is crucial. If the socialization and workshops served as communication channels, the communicator would have to understand the substance of child-related issues. A communicator would need to be attractive, clear, and skilled in communicating matters related to children, in a lucid manner appealing to children. Such communicators could be experts or professionals selected by the DP3AP2KB based on their expertise.

\subsection{Message}

Based on the research known that the DP3AP2KB concern - as the CFC policy coordinator for the content of the message in all CFC policy publication is very weak. They do not focus at the message in all CFC Policy publication. This was apparent from the in-depth interviews of some informants from the targets audience. Many target audience members did not understand the content of these messages. In fact, the message was being an effort in driving people objective to change their attitude or caprice. The essence of the messages will be always lead to the last objective of communication. As a communicator of the CFC policy at the local government level, the DP3AP2KB plays an important role in determining the messages to be distributed to target audience. These messages should be considered in terms of the clarity of the message. For example, a message to a target audience must be clear and avoid confusion. A billboard message about the CFC, for example, shall elaborate in a clear, accurate, and compelling way that children have 31 rights to be fulfilled.

\subsection{Channel}

Channels of communication transmit messages related to the CFC to the target audience. In accordance with a George C .Edward III perspective in Agustino, "the use of precise communication channels in a public policy will result in effective implementation" [7].

Besides outdoor media, other communication channels used for media promotion, communication, information, and policy education on CFC initiatives in Kabupaten Bogor are socialization and workshop activities. However, activities as a channel of communication are less effective because they cannot reach large target audiences. Disseminating posters and advertising socialization and workshop activities to broader target audiences should be done consistently to obtain the maximum impact.

In addition, there should be dissemination of information to remote areas and develope convenient access to information for children with special needs (ABK) and from vulnerable groups, such as the poor, minorities, and disaster victims. Access to information for these groups must be free of charge. The use of social media as a communication channel is highly recommended for disseminating messages widely and quickly. The use of media social is also recommended based on the current tendency of children to prefer purchasing internet quotas to phone text message credits.

\section{Conclusions}

Communication plays an important role in the implementation of the CFC policy. The development of a communications strategy for implementing the CFC policy needs to take into account. The communication of public policy involves the DP3AP2KB, the local governmental decision maker, as well as the DP3AP2KB (the office for Women Empowerment, Child Protection, Population Control, and Family Planning Agency) and Diskominfo (the Regency's 
Communication and Information Office). Communication also plays a very significant role in disseminating messages related to the CFC information policy, program, activities, and services to the public. In distributing this message, the DP3AP2KB, as a communicator, needs to join forces with Diskominfo as the channel provider and the Children's Forum as the information channel connecting local governments with children and adults. The development of a communications strategy for the CFC policy through the PCIE must adhere to the model proposed by Lasswell in Ruben dan Steward, "for maximum benefit: a) Speaker, (b) Message, (c) Channel, (d) Receiver, and (e) Effect" [8].

\section{Acknowledgement}

This research and the production of this article is made possible with the support of the PITTA scheme from the University of Indonesia.

\section{References}

1. Kabupaten Layak Anak. Retrieved from www.kla.or.id

2. Kementerian Pemberdayaan Perempuan dan Perlindungan Anak Republik Indonesia. Kabupaten/ Kota Layak Anak: Bahan Advokasi Kebijakan KLA

3. Riggio, Eliana. Child Friendly Cities: Good Governance in the Best Interests of the Child. Environment \& Urbanization, Vol. 14 No. 2, pp. 45-58. https://doi.org/10.1177/095624780201400204. (2002)

4. Corsi, Marco. The Child Friendly Cities Initiative in Italy. Environment \& Urbanization, Vol. 14 No. 2 October 2002, pp. 169-197. http://journals.sagepub.com/doi/abs/10.1177/095624780201400214 (2002)

5. Neuman, W. L., \& Kreuger, L. Social Work Research Methods Qualitative and Quantitative Approaches. Boston, MA Allyn and Bacon. (2003)

6. Website Resmi Pemerintah Provins Jawa Barat. Penduduk. Retrieved from http://jabarprov.go.id/index.php/pages/id/75 (2017)

7. Agustino, Leo. Dasar-Dasar Kebijakan Publik. Bandung: Alfabeta. 149. (2006)

8. Ruben, Brent D. \& Steward, Lea P. Communication and Human Behavior (5th ed.). Boston: Pearson. (2006) 